\begin{tabular}{l|l} 
THE RECONSTRUCTION OF THE VOCABULARY \\
OF MATERIAL CULTURE AND THE TIME DEPTH \\
OF A LANGUAGE FAMILY (MILITARY TERMINOLOGY \\
IN THE PROTO-INDO-EUROPEAN LANGUAGE AND ITS \\
SUBCLADES) \\
\\
$\begin{array}{l}\text { Keywords: vocabulary of material culture; semantic reconstruction; military } \\
\text { terminology; Indo-European languages. }\end{array}$
\end{tabular}

The article explicates some methodological principles that should be observed when working with the reconstruction of semantic tokens to the proto-linguistic level, and criticizes the insufficiently clear observance of them in the version of the Afrasian lexical reconstruction proposed in Alexander Militarev's article on the "Lexical Reconstruction for the Reconstruction of the Prehistory: ProtoAfrasian Terms Related to Weaponry, Warfare and Other Armed Conflicts”. I offer a reconstruction of the vocabulary presumably related to war and weapons in the Proto-Indo-European language and its early subclades (a time depth of at least 3.5 thousand years from the present time), and make a quantitative assessment of the Proto-Indo-European "lexicon of war" in comparison with the supposed Proto-Afrasian one.

This article is a translation of: Дыбо А.В. Реконструкция лексики материальной культуры и историческая глубина семьи языков (военная лексика в праиндоевропейском языке и дочерних группах) // Etnograficheskoe Obozrenie. 2021. No 4. P. 50-62. DOI: $10.31857 / \mathrm{S} 023620070016698-4$

Article by A. Yu. Militarev examines valuable etymological material, with the help of which the author tries to justify the assertion that the speakers of Proto-Afroasiatic language (presumably, inhabiting Levant in the 11th - 10th millennia BC) were aware of the phenomenon of "war". The issue of the existence of wars during primitive era, as we can see, is controversial for historical anthropology, not least due to disagreements regarding the definition of the term "war". A. Yu. Militarev intends to propose new material to solve the issue by reconstructing the zone of the Proto-Afroasiatic vocabulary related to military actions. Without doubting the value of his etymological proposals and not being an Afrasian languages expert I, as a specialist in semantic reconstruction who has engaged herself, in particular, in weapons and social vocabulary in the languages of other families (see: Dybo 2005; Dybo, Normanskaya 2014; Dybo 2011, 2015), would like to present some comments regarding the applied methodology and, accordingly, the status of the conclusions made:

1. As for the work with lexical semantics and its reconstruction, the author writes the following:

Taking into account all the actual difficulties and nuances of translation in all the languages, both extinct ancient and living, the term "war" usually differs from the terms "struggle", "skirmish", "robbery", "raid" and others, present in the same semantic field. If, in a representative sample of daughter languages, related words mean precisely "war" (and it can be justified that they are all inherited from a proto-language, and not borrowed later), then

Anna Dybo | https://orcid.org/0000-0002-6077-7183 | adybo@mail.ru | Institute of Linguistics, Russian Academy of Sciences (1 bld. 1 Bolshoy Kislovsky Lane, Moscow, 125009, Russia)

Etnograficheskoe Obozrenie. 2021. № 4. P. 274-283. https://doi.org/10.31857/S086954150016799-8

(C) Russian Academy of Science | (C) Institute of Ethnology and Anthropology, RAS

ISSN 0869-5415 | http://journal.iea.ras.ru 
it is extremely unlikely that a proto-linguistic term with a different meaning - say, "fight", in different daughter languages, was independently replaced by "war", that is, so that in the proto-language the corresponding reconstructed word meant something different than "war", with the basic set of associations that term once had among native speakers.

However, in general, we cannot reconstruct "the meaning of this term that was once associated with it by the proto-language speakers". There is no abstract meaning of "war" similar for different languages (and proto-languages), just as there is no abstract meaning of the "dative case". When we reconstruct the meaning of "dative case" for a certain protolanguage morpheme, as well as when describing morphology of a certain language and stating that this or that morpheme is the dative case in its system of nominal inflection, we imply that, apparently, this morpheme was used in the proto-language (is used in this language) to denote the actant function of the addressee. At the same time, it could (can), additionally, express the function of the end point of movement, of the experiencer (the subject of perception), of the chomage agent (for example, a subject in a passive structure) - or it could not. The semantic role of addressee is the core role for the dative case. If in the recovered system of case morphemes, in addition to our "dative", a separate morpheme exists for which we can restore the function of expressing the end point of movement, then we will ascribe to it the grammeme of allative and then decide whether or not our reconstructed dative expressed this function too. However, without reconstructing the system we cannot say anything definite about the functions set of this morpheme, state that, for instance, it combines all the listed functions on the basis that the "dative" we have highlighted in Turkish or Russian combines these functions.

Quite similarly, to restore meaning of a certain reconstructed lexeme, as well as to register true interpretation of the lexeme in a dictionary of the language under consideration, we need to establish both the microsystem of lexemes that includes this lexeme and which semantic characteristics work as distinctive ones in this microsystem. To do that for an ancestor language, it is necessary to define relevant microsystems and their distinctive characteristics for at least a part of compared languages (usually, in order to do it correctly, one needs to establish diagnostic contexts of usage of these words, which requires either a targeted poll [see, e.g., the works of the school of E. V. Rakhilina: Rakhilina, Kholkina 2019], or a sufficiently large corpus of texts in the language [see Dybo 2013; Kassian et al. 2010]).

There is another important matter. The author states in footnote 7: "In comparativehistorical linguistics ... semantic comparison criteria remain 'humanitarian', often based on obviousness and common sense." However, comparative historical linguistics and historical typology of semantic changes have been developing more stringent criteria for semantic comparison (see reviews: Dybo 1996, 2011). The simplest of them is to establish availability of an example of polysemy of a lexeme in any existing language (using a formal criterion for distinguishing between polysemy and homonymy).

In particular, the statement "in all the languages, both dead and living, the term "war" usually differs from "struggle", "skirmish" ,"robbery", "raid" and others in the same semantic field" does not seem reasonable. Polysemy of lexemes is quite real in this semantic field. Compare in Russian:

ВОЙНА ('WAR')... 1. Organized armed struggle between states or social classes ... 2. ... State of animosity; struggle with someone, something ...

БОЙ ('FIGHТ')... 1. Battle, fight; action as per verb. beat (in the 1st value) ... 2. Struggle, competition ... 3. ... Action according to the verb. beat (in the 2nd meaning); beatings, drubbing ... 4. Action as per verb. beat (in the 4th meaning); slaughter ... 5. Action as per verb. to beat (in the 5th meaning), as well as the lethality of firearms ... 6. Action as per verb. beat (in the 6th meaning); Breakage of dishes. 7. collect. Broken, hacked to pieces - glass, clay, etc. dishes, broken objects ... 
8. Action as per the verb. beat (in the 7th and 8th meanings), as well as the sounds of this action. Drum beat ...

БОРЬБА ('STRUGGLE') ... 1. Close combat of two, where each tries to overpower the other one ... $\|$ Fray, battle ... 2. An active conflict of opposing social groups, opposing trends, interests, etc., where each side seeks to dominate, preponder ... (Evgenieva 1999);

in Turkish: savaş 1) war, 2) struggle (Baskakov et al. 1977); in English: War ... 4) ... any kind of struggle or conflict (Hornby 1974), etc. See also the interpretation of Russian words of this circle in works devoted to creation of an explanatory-combinatory dictionary (Apresyan et al. 1984; Apresyan 2014a, 2014b; Boguslavskaya 2014; Krylova 2014; Lopukhina 2014, etc.).

At the same time, in order to make historical implications, one must nevertheless distinguish between the meanings of "war = a sequence of armed conflicts between societies (= organized groups of individuals) where intentional slaughters can occur", "battle = fray = a single armed conflict between societies, where intentional slaughters can occur", and "combat $=$ a single armed conflict between individuals or societies where intentional slaughters can occur", and also "struggle = conflict between individuals or societies", "fight = a single conflict between individuals or societies, in which attempts to inflict injury may occur," etc. It is obvious that archaeological evidence (burials with traces of traumas made by weapons, and traces of mass slaughters of different groups representatives), taking into account these differences, can be the evidence of battles, but not wars. One could imagine archaeological confirmation of a war in the form of evidence of several geographically closely discovered, closely dated battles, where the victims would be identified as carriers of two or more different material cultures and members of two or more genetically/anthropologically related groups; but such evidence for prehistoric times seems to have not yet been provided ${ }^{1}$.

Evidence of semantic changes possible for a given lexical-semantic field in the world languages can be found primarily in the "Catalog of Semantic Changes", created by a team led by A. A. Zaliznyak. The meanings "war" and "to war" have the following shifts:

\begin{tabular}{l|c|c|c|c|c|c|c}
\hline ID & Class & Meaning 1 & Direction & Meaning 2 & Status & & \\
\hline 845 & $\mathrm{~V}$ & to be at war & $\rightarrow$ & to quarrel & IG & Open & Show map \\
\hline 2393 & & to beat, hit & $\rightarrow$ & to be at war & MR & Open & Show map \\
\hline 2394 & & to kill & - & to be at war & MR & Open & Show map \\
\hline
\end{tabular}

(see: CSSh-1)

\begin{tabular}{l|c|c|c|c|c|c|c}
\hline ID & Class & Meaning 1 & Direction & Meaning 2 & Status & & \\
\hline 0831 & & $<$ weapon $>$ & $\rightarrow$ & war & Accepted & Open & Show map \\
\hline 2684 & & $<$ weapon $>$ & $\rightarrow$ & army & Accepted & Open & Show map \\
\hline
\end{tabular}

(see: CSS-2)

\begin{tabular}{l|l|l|l|l|l|l|l}
\hline 3083 & & enemy & $\rightarrow$ & war & New & Open & Show map \\
\hline
\end{tabular}

(see: CSS-3)

\begin{tabular}{l|c|c|c|c|c|c|c}
\hline ID & Class & Meaning 1 & Direction & Meaning 2 & Status & & \\
\hline 2819 & & $\begin{array}{c}\text { ear, spike (of a } \\
\text { grain plant) } \\
3206\end{array}$ & - & <weapon> & Single* & Open & Show map \\
strength & $\rightarrow$ & <weapon> & New & Open & Show map \\
\hline
\end{tabular}

(see: CSS-4)

The shown database is far from completeness; moreover, it is not always possible to trust the directions of semantic shifts indicated therein. For example, the shift "weapon> war" is implemented as ancient Greek. $\dot{\alpha} \sigma \pi i \varsigma$ "shield; battle", but the meaning of battle is assumed 
to be the use of the word in the expression, that literally means "to stand behind the shield" (Liddell, Scott 1996: 259) (fig. "to take part in the battle"). In this case, it all boils down to a textbook error of a lexicologist: to give the meaning "relative" to the word second, guided by its use in the expression "second cousin twice removed ". A phraseologized expression can, in principle, result in development of a specific meaning; compare French. voler "fly; steal", the second meaning of which (and a modified government model; the verb in this meaning has become transitive) goes back to the specific falconry sublanguage - le faucon vole la perdrix "the falcon catches (in flight) a partridge" (Benveniste 1954: 252) - and further to the thieves' argo. However, such developments are not standard and require special justification.

For a number of comparisons proposed in the article, the reconstruction of the "weapon" meaning, at least based on the materials presented in the article (I suppose that the author may have some additional reasons for semantic solutions), seems farfetched.

For example, the meanings presented for *ma/itw- *may/wt- "club (including throwing club)" really are such: "stick", "staff", "rod", "whip", "long pole", "spear". The meaning of "club" is found only in Accadian; "throwing club" is in the least a highly specific type of weapon (light, flat, curved, like a boomerang; see: Gorelik 1993: 61), and such a meaning is not given in any real language in the article. It is hard to imagine a scenario where a word with such a meaning would turn into a designation of a rod or a pole - the development into a "throwing spear" and further "an arrow" can only be imagined. The most evident common meaning here is just "stick". Similarly, *faya?- "edging, arrow" for the Proto-Semitic condition can be reconstructed, most likely (based on the presented material), in the meaning of "edge, blade", for Chadic - "to jab, to pierce", for Cushitic - "arrow"; for PAA, the semantics results in "sharp edge/end". The meaning of "sling" for PAA *kVla $\zeta$ - is presented only for Proto-Semitic, in Chadic - the main meaning is "to throw with force", in Cushitic "scourge", "stick" and "bow", which most likely go back to the general meaning "stick, shaft" and are unlikely to relate to the NAA root, which probably meant "to throw with force."

2. The Proto-Afroasiatic condition, for which the article proposes reconstruction, dates back to the 11th -9 th millennia BC. The author reconstructs 12 words - names of weapons with different degrees of reliability, according to him, and 13 words related to the military operations sphere. It would be interesting to examine how the vocabulary of the same group can be restored for the younger language families of the Old World. The simplest assessment to make would be for the currently most-developed reconstructed vocabulary of the IndoEuropean family.

\section{The Indo-European family}

The first split into Anatolian and narrow Indo-European families dates back to approximately the 5th millennium $\mathrm{BC}$, the second one - the breakaway of the Tocharian group - to approximately the 4th millennium BC. Further classification - up to the late groups that split at the turn of the 1st millennium $\mathrm{BC}$ and at the turn of $\mathrm{CE}$ - is not quite clear, that is, it is not clear which associations should be considered areal and which are genetic. Here I will conditionally rely on the classification associated with archeological and glottochronological data, by V. A. Dybo (Dybo 2006), since it also covers complex sequences of morphonological processes in various groups of Indo-European languages. It assumes the presence of the genetic northwestern group (disintegration in the middle of the III millennium $\mathrm{BC}$ into Celtic-Italic, Germanic and Balto-Slavic; the split of the latter - the very end of the 2nd millennium BC) and the southeastern, Greek-Aryan group (disintegration at early 3rd millennium BC into the Greek, Albanian, Armenian and Indo-Iranian). We present the reconstruction of the "military" lexical group based on the work of T.V. Gamkrelidze and Vyach.Vs. Ivanov and G. Mallory and D. Adams (Gamkrelidze, Ivanov 1995: 643-645; Mallory, Adams 1997, 2006), as well as the database on Indo-European etymology (Nikolaev, 
n.d.) and etymological dictionaries. Moreover, we take into account some of the findings of an ongoing study by the group of Nostratic Seminar named after V. M. Illich-Svitych (Starostin et al. n. d.) on the recoverability of basic concepts for the ancestor languages of the Old World language families.

Weapon $^{2}$. As it is correctly mentioned by A. Yu. Militarev, strictly speaking, it is impossible to establish for almost any weapons reconstructed for the proto-language, whether they were used for military actions or only for hunting. Defensive weapons (shield, helmet, etc.), the use of which in hunting is doubtful, are the exception. We will, however, consider all the recoverable weapon names. Let us distinguish between $\mathrm{PIH}$ - the words, recovered for a proto-language before the second split, that is, those the reflexes of which are also present in Anatolian or Tocharian languages, PIE - the words narrowly reconstructed only for Indo-European, PNIE - "Proto-Northwest" and PSIE - "Proto-Southeast". Let us quote here the already established opinion of Indo-Europeanists immediately:

Considering the variety of the military weapons names in certain historical dialects (cf. Schrader 1886: 324-325), it is almost impossible to find etymologically related names of weapons going back to the Indo-European community period, or at least to more or less ancient dialect communities. The explanation to this should be found in the constant replacement of military weapons names, depending on the change and improvement of manufacturing technology in individual historical associations of tribes (cf. a similar situation with regard to the names of specific craft tools) (Gamkrelidze, Ivanov 1984: 739-740).

Ax. (?) PIH *a/odhes- "ax adze" (*hed ed es): Hitt. ates n., atessa- c. "axe" (Tischler 1977: 94); Germ. *adas-an- m.: Old Eng. adesa, adosa "adze"; Ital.: (?) Lat. asser, -eris m. "thick beam, carrier", assis, -is m. "board", dimin. assula f. "chip" (see about phonetic complexities: De Vaan 2016: 58). || Formally, it has "Indo-Hittite" distribution, but in fact, out of "narrow Indo-European" languages it is reliably represented only in ancient (and modern) English. It is possible that the similarity of Old Eng. adesa "adze" and Hittite ates ( $\mathrm{sa}$ ) is occasional, and the Latin form does not belong here.

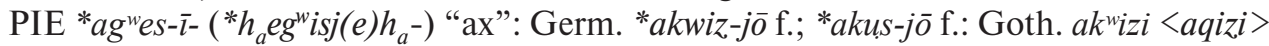
etc.; It.: Lat. ascia f. "ax, used by carpenters, masons and in agriculture, trowel”; Greek Mycenaean $a$-qi-ja "ax", (?) Ancient Greek $\alpha^{3} \xi i v \eta$ "ax" (the Greek word is not a direct descendant of the Mycenaean one and, rather, is associated with Accadian hașșinnu "ax", herewith it is clear that the word is borrowed from Semitic into Greek, and not vice versa, since otherwise it is impossible to explain the initial h- in Accadian). $\|$ PIE commonality due to the Mycenaean form.

G. Mallory and D. Adams (Mallory, Adams 1997: 38) also note numerous derivatives of the verb *teks - "to create" with the meaning of various tools (axes in particular) and products (fabrics in particular), however, since in different languages they form using different suffixes (the exception is Celtic-German-Slavic *teks-leh "ax, adze": OE tāl "ax", OHG dehsala "adze, hatchet", PSlav. *teslo "adze", but here the suffix is productive, so parallel verbal word formation is also possible), it is impossible to restore the proto-language name of the tool.

(?) PIE *krwi- "sickle, ax, sword": Celtic: Middle Irish pl. acc. coire "swords"; Slav. PS1

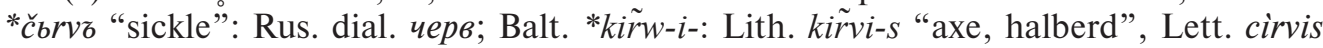
"hatchet”; (?) IIran. Skt . krwi-“tool used by a weaver”. \| (Walde 1930: 573). M. Mayrhofer considers the comparison with Skt. semantically unreliable (Mayrhofer 1953: 262).

(?) PNIE *sek-ūr-: lat. secūris "ax", PS1 *sekyra "ax". \| Reflexes are presented in Latin and Slavonic. Derived from the verbal root *sek- "to cut", but the model is non-trivial and coincides in geographically distant languages, so this derivative should have already existed in Proto-Indo-European, unless, of course, it is a borrowing into Proto-South Slavonic from Latin, which subsequently spread with Church Slavonic texts. (hypothesis by T. V. Gamkrelidze and 
Vyach.Vs. Ivanov [Gamkrelidze, Ivanov 1995] on borrowing by PIE from Accadian šukurru "ax" is now commonly viewed as groundless.)

PSIE *pelekius: Ancient Greek pélekü-s, -eōs m. "axe, halberd"; IIran.: Skt. párśu- m. "crooked knife, sickle", paraśú- m. "ax, hatchet"; Osset. färät and Khot.-Saka pada(<*parta-) in Iranian languages. V. I. Abaev ${ }^{3}$ offers the following phonetically verified explanation: Osset. form is an ancient ("even during the Scythian era") borrowing from an unattested Ancient Persian *para $\theta u$-, which would be a natural correspondence to PIran. *parasu- <IIran. *paraśu- (Abaev 1958: 451). Obviously, the same ancient cultural borrowing has to be adopted for the Saka; then Tocharian B peret "ax", A porat "ax" (Adams 1999: 396: PTochar. *peret - a borrowing from some Middle Iranian source) should be considered a borrowing from this borrowed Saka form ${ }^{4}$. An Alanism is apparently present in the VolgaBulgar - Chuv. port(z) "ax" (Fedotov 1996: 447-448); Permian forms should also be considered Alanisms: Proto-Komi *purt, *purt-əs; Proto-Udmurt *purt, *purt-es "knife"; Zyryan purt "knife", purtzs "sheath; shuck"; Udm. purt "knife" and purtes "sheath; shuck" (Lytkin, Gulyaev 1970: 233; see also: Dybo 2007: 131). || Reliably reconstructed for the "Graeco-Aryan" dialectal region of Proto-Indo-European in the meaning of "ax" (as a tool and as a weapon), but it has limited distribution and phonotactically does not look like an original word (a trisyllabic root!). The opinion widespread in etymological literature about borrowing from the Accadian pilakku is false, since the Accadian word means "spindle".

Club. All the potential forms proposed by G. Mallory and D. Adams (Mallory, Adams 1997: 112) for this meaning are either local (like Celtic-German *lorgeh ${ }_{a}$, for which a borrowing is also possible from Celtic to Old Norse - and then it is only Celtic), or by verbal derivatives with the use of different suffixes in different groups. The most seductive proposal is:

(?) PIE *waĝros "club?, hammer?": (?) Germ. proper names: Goth. Odoacer, Old English Eadwacer $<$ PGerm *Auda-wakraz, if they can be interpreted as "having many weapons"; Ancient Greek proper name Meléagros $<*$ mele-wagros "taking care of the club"(?); IIran. Avest. vazra- "club, hammer", Skt. vájra- "throwing weapon of the thunder god" (borrowed to Tochar. AB wäsír "lightning"). | Derivative of the verb *wâg- "to strike, split".

Knife. PIH *wēben- "cutting weapon, knife": Tochar. AB yepe (A is borrowed from B) "knife"; Germ. *wēb-no-, Old Norse va:pn "weapon" (axe, sword, spear), Old Eng. wae:pn "weapon, sword" (> Modern Eng. weapon), Goth. pl. we: pna "weapon". \| The verbal root seems not to be separately fixed (see: Rix H. et al. 2001).

(?) PIH *kert- "knife": Tochar. B kertte "sword". IIran.: Avest. karəti- "knife", Skt. $k_{o} r_{i}$ - "knife". \| A derivative of the verb *(s)ker- "cut". The comparison is not reliable enough: the Tocharian form could have been borrowed from Iranian.

(?) PIE * $k^{e} s$-trom or * $k^{e} s-d^{h}$ rom "cutting tool, knife": Lat. castrō "crop, cut, castrate" (denominative verb from non-recorded *castrum "cutting tool"); Alban. thadër $<* k o s$ $d^{h}$ rom "kind of adze"; Skt. śastra- "knife, dagger". \| A derivative from the verb *kes- "cut" + productive suffix of tool names ${ }^{*}$-trom or ${ }^{*}-d^{h}$ rom. Since the suffix is productive, independent formation in different branches is possible in general.

(?) PIE *kl-tēr "knife": Lat. culter "knife (of a butcher)"; Skt. kuthāra- "ax". \| Derivative with productive agent or instrument names suffix from the verb * $(s)$ kel- "cut, split". Since the suffix is productive, independent formation in different branches is possible in general.

Sword. PIH *nsis ( ${ }^{2} h_{2 / 3} n_{s}$ sis ) "big knife, sword": Anat. Palaic hasīra- "dagger"; Lat. ènsis, -is m. "sword"; IIran. Avest. ayhū- "sword, knife", Skt. asī- "sword, slaughter's knife". \| A nominative root; a reliable PIH word.

PIE(?) *skolmeh $a^{-}$"sword": Germ. Old Norse. skglm "sword"; Thracian skálmēe "sword, knife".

Spear. PIE * $g^{w}$ eru "spear staff": Lat. verū, gen. verus, pl. verua n. "skewer", Umbr. berus "verubus", berva "verua" "skewer, spear"; Old Irish biur "spear, skewer", Welch ber "spear, skewer"; IIran. Avest. grava- < * gwrewo- "staff". 
PIE *h $h_{a}$ eksmo/eh $a^{-}$"spear": Balt. Old Prus. aysmis "skewer”, Lith. iẽšma-s, jiẽšma-s "skewer, spear", Lett. iesms "skewer"; Ancient Greek aikhmä̈ "spearhead, spear". ॥ Derivative of the verb *h $h_{a} e k^{\wedge}$ "to wound with a sharp object".

PIE * $\hat{g}^{h}$ ais-o/e-s "throwing spear, dart": Celt. Old Irish gae "spear", Welch gwayw "spear", gallo-roman gaesum "spear", Germ. Old Norse geirr "spear", Old Eng. gar "spear", Old High German ger "spear", Goth. Gaisa-reix "king of spears" (personal name; < PGerm. *gaizaz); Ancient Greek khâio-s m., khâio-n n. "shepherd's staff”; Skt. heșas- n. "projectile". || Derivative of the verb * $\hat{g}^{h} h_{a} i$ - "throw" (?).

Arrow (?) PNIE *streHlā ( ${ }^{*}$ streh $\left.h_{x} l(e) h_{a^{-}}\right)$: Germ. *strēlo f. "arrow; metaph. ray": Old Eng. stræl "arrow", OSax. strāla, id., OHG strāl id., strāla id. etc.; Slav. *strěla; Balt. Lith. strèlà, Lett. strę̄la "Geschoß, Pfeil, Streifen". || G. Kroonen considers the Slav. word to be a Germanism (Kroonen 2013: 484). E. Fraenkel, on the other hand, considers borrowing to Balt. from Slav. impossible for phonetic reasons (Fraenkel 1965: 920-921). If, as it is presumed by E. Fraenkel, we deal with the original Balto-Slavic word, then a Germanism is hardly possible.

PSIE *isu-s (*h $h_{1} e i s u s$, Gen. * $\left.h_{1} i s w o s\right)$ : Ancient Greek ios "arrow"; IIran. Avest. išu- m. "arrow”, Skt. ișu- m. f. "arrow". \|A "Graeco-Aryan” comparison. Cf. the verb Hitt. išhuwa"to scatter, to throw" (Tischler 1977: 393).

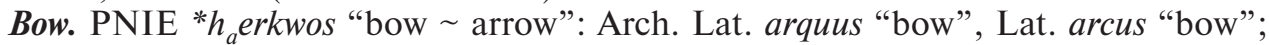
Germ. *arhō, Old Norse $q r$ "arrow", Old Eng. earh "arrow" (> Modern Eng. arrow), Goth. arhazna "arrrow". || It is considered either to be derived from a verb meaning "to bend" (but a good comparison is unavailable), or related to a group of tree names (Rus. rakita and so on); it can be possibly singled out as a separate PNIE word.

(?) PSIE *toksom "bow": Greek Mycenaean to-ko-so-wo-ko "bow-makers", Ancient Greek tókso-n "bow", Iranian Scyth. taxsa "bow", Middle Pers. tax̌̌ "bow". \| Usually the Greek word is considered a borrowing from Scythian, and all together as a metonymy of *toksom "yew" as a wood the bows were made of.

Bowstring. PSIE * $g^{w} e y \bar{a}\left({ }^{*} g^{w} e y(e) h_{a}\right.$, Gen. * $\left.g^{w} i h_{a} o s\right)$ "bowstring": Ancient Greek bió-s m. "bow"; IIran. Avest. jya "bowstring", Pers. zih "bowstring", Skt. j(i)yā "bowstring". \| PIE meaning is rather "tendon, thread", cf. NIE forms of the same base: Celt. Cymr. pl. giau "tendons, nervs", Slav. *ž̌c $\bar{l}$ "thread; yarn", Balt. Lith gijà "warp threads".

Shield. PNIE *ske/oits (gen. *skitos) "shield; board": Lat. scūtum "shield" ( skoitom); Celt. Old Irish sciath "shield", Welsh ysgwyd "shield"; (?) Germ. Old Eng. scìd "slug", OHG scit "board, plank"; PSlav. *ščìt " "shield"; Balt. Old Pruss. staytan (erratum: instead of *scaytan < *skoitom), Lith. skĩ da-s m. "shield".

The meaning "shield" seems to not be reconstructed for PIH *spelo/eh $a^{-}$: Anat. Luw. palahša- " \pm blanket, fur coat" (not "shield", contrary to the interpretation by T. V. Gamkrelidze and Vyach. Vs. Ivanov [Gamkrelidze, Ivanov 1995: 644]); Germ. Old Norse fjol "board; IIran. Ancient Pers. spara-barai "shield bearers", Middle Pers. ispar "shield", Skt. phálakam "shield, board". || It is derived from the verb * $(s) p(h) e l-$ "rip off", i.e. "animal skin" is probably primary. The meaning of "shield" appears only in IIran.

War. The word with the meaning "war" is not reliably recovered for Proto-IndoEuropean, but there is vocabulary indicating participation in battles.

Army. PIE *koros and derivative *korjos "army, military squad": Celt. Middle Irish cuire "squad; army", Germ. Goth. harjis "army”, Balt. Lith. kãras, Lett. karš "war”, Old Lith. kãrias "army, squad; war", Old Pruss. *kargis (written as kragis) "army"; Ancient Greek

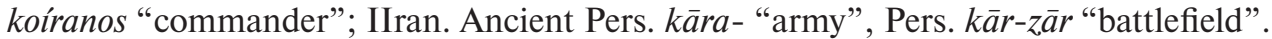

PIH *laH(w)o- (*leh,wos) "battle, army": Anat. Hitt. lahha- "battle", Greek Mycaen. ra-wa-ke-ta = lāwāgetās "commander", Dor. lāgétās "demagog", Phryg. lawagtaei "commander" (Dat.), Ancient Greek lāwós "people”, pl. "army".

Battle. PNIE *katu- "battle": Celt. Old Irish cath "battle", Germ. OHG hadu- "battle", Slav. *kotora "battle". 
PNIE *weik- "combat: Lat. vincō "I win; Celt. Old Irish fichid "battles", Germ. Old Eng. gewegan "to battle"; Balt. Lith. apveikiù "I win".

Enemy. PSIE *dus-menēs "hostile", Ancient Greek. düsmenês "hostile", Avest. dušmanah- "hostile", Skt. durmanās "sad". || Composite "bad+thought".

See also E. Benveniste (Benveniste, 1969), who reliably reconstructs two Indo-European property terms related to military actions:

PIH *soru- "spoils (at looting)": Anat. Hitt. sāru "spoils, captives"; лат. servus "slave"; Celt. Old Irish serb "looting", Welsh herw "raid for cattle";

PNIE *lau- "spoils (military or hunting)": Lat. lucrum $(<* l u-t l o-m)$ "gain, advantage"; Old Irish lóg "earnings, price"; OHG lōn "compensation, payment" (Germ. Lohn), Goth. laun "payment", cf: Old Slav. lovü "spoils of the chase, catching".

So, for PIH we have: 3 reliable and 2 possible names of weapons, 1 name of an army and 1 name of spoils - 7 in total. For PIE: 7 reliable and 7 possible names of weapons, 2 names of armies - 16 in total. For PNIE: 6 reliable $\left({ }^{*} h_{a} e g^{w} i s j(e) h_{a^{-}},{ }^{*} k r_{o} w i-,{ }^{*} g^{w} e r u,{ }^{*} \hat{g}^{h}\right.$ ais-o/e-s,

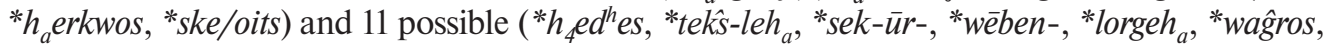

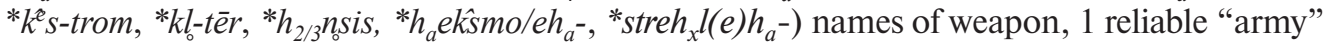
(*koros), 1 reliable "battle" (*katu-), 1 reliable "to fight" ( *weik-), 2 reliable "spoils" ( , *lau-) - that is 22 in total. For PSIE: 5 reliable (*pelekus, *waĝros, ${ }^{*} \hat{g}^{h}$ ais-o/e-s, ${ }^{*} h_{l}$ eisus,

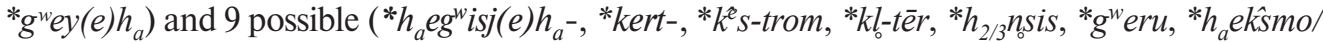
$e h_{a^{-}},{ }^{*}$ toksom, ${ }^{*}$ spelo/eh $\left.a^{-}\right)$names of weapons, 1 reliable $\left({ }^{*}\right.$ koros $)$ and 1 possible $\left({ }^{*}{ }^{*}{ }^{*} h_{2}\right.$ wos $\left.^{2}\right)$ name of an army, 1 reliable "enemy" (*dus-meness) - 17 in total. Total number of reconstructed words obviously increases with the decrease in depth of the assumed linguistic community. In total, 12 reliable and 10 possible names of weapons, 7 reliable words related to military actions have been recovered. As we can see, the number of words from military field reconstructed for the Proto-Indo-European strate (fifth millennium BC) with a certain degree of reliability ( 29 words) is comparable to the amount recovered for the Proto-Afroasiatic (tenth millennium BC; 24 words). But, as we tried to show, the selection into the Proto-IndoEuropean vocabulary is performed by several orders more thoroughly, in particular, the reconstruction of semantics is performed stepwise as far as possible, that is, the meaning is established within each group of languages, and on the basis of these meanings a IndoEuropean word is reconstructed; additionally, word formation is taken into account. It seems these factors all the more should be taken into account in the work with distant comparisons.

\section{Notes}

${ }^{1}$ Though there seems to be no reason why, in the presence of organized groups of individuals proven to be able to perform armed conflicts, such relationships would not systematically arise between such groups.

${ }^{2}$ The semantic reconstruction below (and the interpretation of the recorded words) rests on a simplified feature set based on the classification of weapons adopted by M.V. Gorelik (Gorelik 1993).

${ }^{3} \mathrm{NB}$ : the entry Hung. bart "ax" mentioned in this dictionary does not exist.

${ }^{4}$ The possibility of transferring " $a$ " through " $e$ " in Tocharian borrowings from Iranian languages was described by Winter (Winter 1984: 45).

\section{References}

Abaev, V.I. 1958. Istoriko-etimologicheskii slovar' osetinskogo yazyka: V 5 t. [Historical and Etymological Dictionary of the Ossetian Language, 5 vols.]. Vol. I. Moscow; Leningrad: Izdatel'stvo AN SSSR. Adams, D.Q. 1999. A Dictionary of Tocharian B. Amsterdam: Rodopi.

Apresian, V.Y. 2014. BITVA [BATTLE]. In Aktivnyi slovar' russkogo yazyka. T. 1, $A-B$ [The Active Lexicon of Russian Language], edited by Y. D. Apresian, 252-253. Moscow: Yazyki slavianskoi kul'tury. 
Apresian, V.Y. 2014. BOI [COMBAT]. In Aktivnyi slovar' russkogo yazyka. T. 1: $A-B$ [The Active Lexicon of Russian Language], edited by Y. D. Apresian, 302-304. Moscow: Yazyki slavianskoi kul'tury.

Apresian, Y.D., L. L. Elnitskii, T. Ya. Kazavchinskaia, and N. V. Pertsov. 1984. BOR'BA [STRUGGLE]. In Tolkovo-kombinatornyi slovar' sovremennogo russkogo yazyka. Opyty semantikosintaksicheskogo opisaniia russkoi leksiki [Explanatory Combinatorial Dictionary of Modern Russian: Semantico-syntactic Studies of Russian Vocabulary], edited by I. A. Melchuk et al., 148-157. Vena: Wiener Slavistischer Almanach.

Baskakov, A.N. et al. 1996. Turetsko-russkii slovar'. 48000 slov [Turkish-Russian dictionary]. Moscow: Russkii yazyk.

Benveniste, É. 1954. Problèmes Sémantiques De La Reconstruction [Semantical Problems of the Reconstruction]. WORD10 (2-3): 251-264.

Benveniste, É. 1969. Le Vocabulaire des institutions indo-européennes [The Vocabulary of InfdoEuropean Institutions]. Vol. I, Économie, parenté, société [Economics, Family Relationship, Society]. Vol. II, Pouvoir, droit, religion [Power, Law, Religion]. Paris: Les Éditions de Minuit.

Boguslavskaia, O.Y. 2014. VOINA [WAR]. In Aktivnyi slovar' russkogo yazyka. T. 2: V-G [The Active Lexicon of Russian Language. Vol. 2], edited by Y. D. Apresian, 221-222. Moscow: Yazyki slavianskoi kul'tury.

De Vaan, M. 2016. Etymological Dictionary of Latin and the other Italic Languages. Vol. 7. Leiden: Brill. Dybo, A.V. 1996. Semanticheskaia rekonstruktsiia v altaiskoi etimologii [Semantic reconstruction in the Altaic etymology]. Moscow: Shk. "Yaz. rus. lit.".

Dybo, A.V. 2005. Names of Gift in Turkic Languages. In Altaiskie yazyki i vostochnaia filologiia:

pamiati E. R. Tenisheva [Altaic Languages and Oriental Philology], edited by K. N. Bicheldei et al., 478-498. Moscow: Vostochnaia literatura.

Dybo, A.V. 2007. Lingvisticheskie kontakty rannikh tiurkov. Leksicheskii fond [Language Contacts by Early Turks: Lexicon]. Moscow: Vostochnaia literature.

Dybo, A.V. 2011. Semanticheskaia rekonstruktsiia v altaiskoi etimologii: leksika konkretnogo slovaria [Semantic reconstruction in the Altaic etymology: the real lexics]. In Slovo i yazyk: sbornik statei $k$ 80-letiiu akademika Y. D. Apresiana [Word and Language: To the $80^{\text {th }}$ Anniversary of Academician Y. D. Apresyan], edited by I. M. Boguslavskii, L. L. Iomdin, and L. P. Krysin, 359391. Moscow: Yazyki slavianskikh kul'tur.

Dybo, A.V. 2013. Etimologicheskii slovar' tiurkskikh yazykov [Etymological Dictionary of the Turkic Languages]. Vol. 9, Etimologicheskii slovar' bazisnoi leksiki tiurkskikh yazykov [Etymological Dictionary of the Turkic Basic Vocabulary]. Astana: Prosper Print.

Dybo, A.V. 2015. Nazvaniia oruzhiia: ot praaltaiskogo k mongol'skomu [The Weapon Terms: From Proto-Altaic to Mongolian]. In Rossiisko-mongol'skii lingvisticheskii sbornik [Russian-Mongolian Linguistic Collection], edited by G.Ts. Piurbeev, 209-254. Moscow: Kantsler.

Dybo, A.V., and Y. V. Normanskaia. 2014. K istoricheskoi tipologii nazvanii oruzhiia v ural'skikh i altaiskikh yazykakh [To the Historical Typology of Weapon Terms in Uralic and Altaic Languages]. Vestnik RGNF 2: 84-100.

Dybo, V.A. 2006. Yazyk - etnos - arkheologicheskaia kul'tura (Neskol'ko myslei po povodu indoevropeiskoi problemy). IV [Language - Ethnos - Archeological Culture (Some Considerations on the Indo-European Problem)]. In Globalizatsiia-etnizatsiia. Etnokul'turnye $i$ etnoiazykovye protsessy. Kn. I [Globalization-Ethnization: Ethnocultural and Ethno-Linguistic Processes], edited by T. M. Skripova, 1: 75-100. Moscow: Nauka.

Evgenieva, A.P., ed. 1999. Slovar' russkogo yazyka: V 4 t. [Russian vocabulary, 4 vols.]. Moscow: Russkii yazyk.

Fedotov, M.R. 1996. Etimologicheskii slovar' chuvashskogo yazyka: V 2 t. [Chuvash Etymological dictionary: 2 vols.]. Vol. 1. Cheboksary: Chuvashskii gos. institut gumanitarnykh nauk.

Fraenkel, E. 1965. Litauisches etymologisches Wörterbuch, 2 Bd. Bd. II [Lithuanian etymological dictionary: 2 vols.]. Heidelberg: Winter.

Gamkrelidze, T.V., and V. V. Ivanov. 1984. Indoevropeiskii yazyk i indoevropeitsy. Rekonstruktsiia $i$ istoriko-tipologicheskii analiz praiazyka i protokul'tury. [Indo-European and the Indo-Europeans: Reconstruction and Historical Analysis of a Proto-Language and a Proto-Culture]. Tbilisi: Izdatel'stvo Tbilisskogo gosudarstvennogo universiteta.

Gamkrelidze, T.V., and V. V. Ivanov. 1995. Indo-European and the Indo-Europeans: Reconstruction and Historical Analysis of a Proto-Language and a Proto-Culture. Vol. 1-2. Berlin: Mouton-de Gruyter. 
Gorelik, M.V. 1993. Oruzhie Drevnego Vostoka (IV tysiacheletie - I Vv. do n. e.) [The weapon of Ancient Orient]. Moscow: Vostochnaia literatura.

Hornby, A.S. 1974. Oxford Advanced Learner's Dictionary of Current English. Oxford: Oxford University Press.

Kassian, A., G. Starostin, A. Dybo, and V. Chernov. 2010. The Swadesh Wordlist. An Attempt at Semantic Specification. Voprosy yazykovogo rodstva 16 (59): 46-89.

Kroonen, G. 2013. Etymological Dictionary of Proto-Germanic (Leiden Indo-European Etymological Dictionary Series). Vol. 11. Leiden: Brill.

Krylova, T.V. 2014. VOEVAT' [TO FIGHT]. In Aktivnyi slovar' russkogo yazyka. T. 2: V-G [The Active Lexicon of Russian Language. Vol. 2], edited by Y. D. Apresian, 187-188. Moscow: Yazyki slavianskoi kul'tury.

Liddell, H.G., and R. Scott. 1996. A Greek-English Lexicon. London: Clarendon Press.

Lopukhina, A.A. 2014. BOR'BA [STRUGGLE]. In Aktivnyi slovar' russkogo yazyka. T. 1: $A-B$ [The Active Lexicon of Russian Language. Vol. 1], edited by Y. D. Apresian, 331-333. Moscow: Yazyki slavianskoi kul'tury.

Lytkin, V.I., and E. S. Guliaev. 1970. Kratkii etimologicheskii slovar' komi yazyka [A short etymological Komi dictionary]. Moscow: Nauka.

Mallory, J.P., and D. Q. Adams, eds. 1997. Encyclopedia of Indo-European Culture. Chicago: Taylor \& Francis.

Mallory, J.P., and D. Q. Adams. 2006. The Oxford Introduction to Proto-Indo-European and the ProtoIndo-European World. Oxford: Oxford University Press.

Mayrhofer, M. 1953. Kurzgefasstes etymologisches Wörterbuch des Altindischen [A short etymological dictionary of Sanskrit]. Vol. I. Heidelberg: Winter.

Rakhilina, E., and L. Kholkina. 2019. Moscow Lexical Typology Group: New Methodology for Lexical Typology. In Essays on Linguistics, 358-380. Beijing: Commercial Press.

Rix, H., et al. 2001. LIV: Lexikon der indogermanischen Verben [Lexicon of Indo-European Verbs]. Wiesbaden: Dr. Ludwig Reichert Verlag.

Schrader, O., and A. Nehring. 1917-1928. Reallexikon der indogermanischen Altertumskunde [Real Lexicon of Indo-European Antiquity]. Vol. I, A-K; Vol. II, L-Z. Berlin: De Gruyter.

Tischler, J. 1977. Hethitisches Etymologisches Glossar. Insbruck: Inst. für Sprachwiss. der Univ.

Walde, A. 1930. Vergleichendes Wörterbuch der indogermanischen Sprachen: In 3 Bd. [Comparative dictionary of the Indo-European languages, 3 vols], edited by J. Pokorny. Vol. II. Berlin: De Gruyter.

Winter, W. 1984. Zur tocharischen Entsprechung von skt. tokharika [To the Tocharian Equivalent of Sanskrit tokharika]. Zeitschrift für vergleichende Sprachforschung 97: 131-134.Stolbova, O.V. 2016. Etimologicheskii slovar' chadskikh yazykov [Chadic Etymological Dictionary].

Moscow: Institut vostokovedeniia RAN. 